Scientific Journal. ISSN 2595-9433

Volume 3, Number 2, Article n. 6, July/December

D.O.I. http://dx.doi.org/10.35418/2526-4117/v3n2a6

Received: 11/27/2020 - Accepted: 01/13/2021

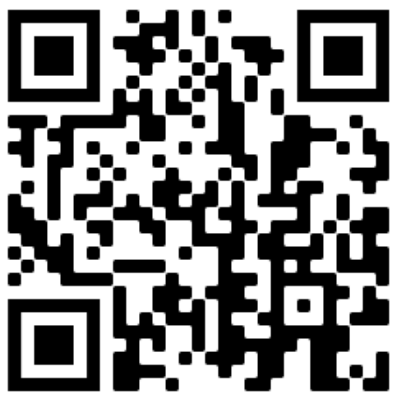

\title{
GENETIC CONTROL OF WHITE LEAF SPOT RESISTANCE AND ASSOCIATION MAPPING IN CORN
}

D Kaian Albino Corazza Kaefer ${ }^{1}$, (iD Adilson Ricken Schuelter ${ }^{2 *}$, (D) Leonardo Balbinotti Bastiani², (D) Guilherme de Sousa Zilli², (D) Ivan Schuster ${ }^{3}$

1 Corteva Agriscience, RS 135 Road, km 17, Coxilha-RS, Brazil;

2 University Center Dynamic of the Falls - UDC, Castelo Branco Street, 440, Foz do IguaçuPR, Brazil;

3 Longping high-tech, Anhanguera Road, km 296, Cravinhos-SP, Brazil.

* Corresponding author: Adilson Ricken Schuelter (adilson schuelter@yahoo.com.br).

\begin{abstract}
This study aimed to evaluate the genetic control of the resistance to white leaf spot (WLS) in corn by the analysis of means and variances and to identify genomic regions associated with resistance. To study genetic control, the parents, F1, F2, and Backcross for each parent were used in field evaluation for WLS resistance. For association mapping, 71 inbred lines were genotyped by SNP markers and phenotyped in the field for WLS resistance in two years. Association analysis was carried out by mixed linear model and multiple regression. The genetic control of WLS resistance in corn is oligogenic, with a small number of genes with additive effects. Association analysis identified three genes for resistance on chromosomes 2, 3 , and 8 , and just the genes on chromosomes 2 and 3 were enough for complete resistance based on multiple regression analysis. Markers identified in this study can be used in Marker Assisted Selection after being validated in specific germplasms.
\end{abstract}

Keywords: Phaeosphaeria maydis, Zea mays, inheritance, association analysis.

\section{Introduction}

In Brazil, the main causes of discontinuity of commercial corn hybrids are new disease epidemics or new strains of pre-existing pathogens previously considered of no economic importance. This is mainly due to the use of susceptible hybrids, monoculture, breeding with no selection for disease resistance, and changes in production systems such as no tillage planting and late growing season (Silva et al., 2015; Kaefer et al., 2019). This is the case of white leaf spot (WLS - Phaeosphaeria maydis (P. Henn.)
Rane, Payak e Renfro), a pest of occurrence endemic, in the way of small and sparse leaf lesions, which began to develop epidemic proportions from on 1990, in several regions of the country (Schipanski, 2011).

WLS is currently considered one of the main leaf diseases of the corn crop. Besides the damages caused in susceptible plants (up to 60\% of production), the disease is wide distributed in all corn growing regions in Brazil (Silva et al., 2015), and in several tropical and subtropical regions of the world (Krawczyk et al., 2010; Sibiya et al., 2011). The disease symptoms are 
characterized by irregular to elliptical leaf lesions, initially light watery green that evolve into necrotic lesions.

Some control measures may help inoculum level and disease damage caused, such as early planting, crop rotation, and fungicide application (Silva et al., 2015). Although the application efficiency with fungicides has increased (Chaves Neto et al., 2017; Borsoi et al., 2018), this disease is difficult to control because the involvement of Pantoea ananatis, since they do not show a secondary action against bacterial diseases (Costa et al., 2012).

The most rational and effective method to control diseases in cultivated plants is genetic resistance (Garrett et al., 2017). However, developing resistant cultivars is an intense work. It involves the identification of sources of resistance, the study of genetic control, and the elaboration and execution of efficient strategies for transferring resistance alleles to the elite germplasm (Schuelter et al., 2003; Mundt, 2014).

Carrying out any breeding program is easier if there is information about the sources of resistance and genetic control of the character. This is because it allows breeders to choose the most appropriate strategy to direct the work of introducing genes into susceptible germplasms and to maximize the exploitation of genetic variability (Pink and Hand, 2003; Van Esse et al., 2020).

Recently, association mapping studies have been developed for qualitative and quantitative traits (Quantitative Trait Loci QTL), aided by SNP molecular markers, to complement genetic inheritance studies with more saturated maps. Association mapping is based on the identification of polymorphisms that correlate with phenotypic variation and, thus, creates associations between genetic markers and phenotype, exploring genetic diversity (Mackay and Powell, 2007). This method can be applied to a series of experimental or non-experimental populations, emerging as an important methodology for mapping genes of interest (Castro and Pereira, 2008; Soto-Cerda and Cloutier, 2012). This study aimed to evaluate the genetic control of WLS resistance in corn by the analysis of means and variances and to identify genomic regions associated with the resistance.

\section{Material and methods}

The experiments were carried out in the experimental field and in the Biotechnology laboratory of the company COODETEC (lat $24^{\circ} 53^{\prime} 8.54^{\prime \prime} \mathrm{S}$, long $53^{\circ} 32^{\prime} 4.72^{\prime \prime} \mathrm{W}$ and alt $678 \mathrm{~m}$ ), in Cascavel, PR, Brazil.

\section{Genetic study}

The genetic populations used in the study of genetic control of WLS resistance in corn were obtained by crossing CD15 x CD69, where the first is highly resistant to WLS and the second is highly susceptible. The F1, F2, BC1.1 (F1 x P1), and $\mathrm{BC} 1.2(\mathrm{~F} 1 \mathrm{x} \mathrm{P} 2)$ populations were obtained by controlled pollination, where $\mathrm{P} 1$ was the resistant parent and P2 the susceptible parent.

The field evaluation was done in complete randomized blocks experiments with three replicates. For parents and $\mathrm{F} 1$ the plots were two rows, for $\mathrm{BC}_{1.1}$ and $\mathrm{BC}_{1.2}$ populations the plots were four rows and for $F_{2}$ the plots were eight rows. Each row had five meters long with 20 plants, spaced 0.25 meters between plants and 0.5 meters between rows. The experiments were planted on March 7, 2016, a late planting time in the second season of corn in Brazil. Late planting time was carried out to favor the development of the disease. In the border of the experiment was planted four rows of highly susceptible hybrid to WLS. In addition, corn stalks with leaves containing WLS disease were placed between the rows in order to increase the source of inoculum of the pathogen in the experiment.

Evaluation of WLS was made at 32 days after flowering, in the grain filling stage using the scores 1 to 6 (Table 1). Due to the difference in segregation, different numbers of plants were evaluated in each population, according to Cruz et al. (2012). In the plots with parents and F1, 12 plants were evaluated, in plots with $\mathrm{BC}_{1.1}$ and $\mathrm{BC}_{1.2}, 48$ plants and in plots with $\mathrm{F} 2$ populations 150 plants were evaluated. 
Table 1. Scores for white leaf spot evaluation in corn.

\begin{tabular}{cl}
\hline Score & Description \\
\hline $\mathbf{1}$ & No lesions \\
$\mathbf{2}$ & Sparse lesions on the plant \\
$\mathbf{3}$ & Up to $50 \%$ of the leaves with lesions, detecting severe lesions in $25 \%$ of the lower leaves \\
\hline $\mathbf{4}$ & Up to $75 \%$ of the leaves with lesions, detecting severe lesions in $50 \%$ of the lower leaves \\
\hline $\mathbf{5}$ & 100\% of leaves with lesions, with severe lesions in $75 \%$ of the lower leaves \\
\hline $\mathbf{6}$ & Dead plant \\
\hline
\end{tabular}

The mean and variance of the segregating and non-segregating generations were used to estimate the effects involved in determining the genetic resistance to WLS, using the weighted least squares methods (Mather and Jinks, 1982; Cruz et al., 2012). The statistical procedures were performed using the software GENES (Cruz, 2013).

\section{Association analysis}

The population for QTL mapping for WSL resistance in corn was composed by 71 inbred lines with different levels of resistance to the disease, from COODETEC germplasm.

For association analysis, the evaluation was carried out in two years, in the planting time of February 2014 and 2015. The plots were evaluated for leaf lesions in the grain filling stage, using the scores described in Table 1. Phenotypic data of the two years were used to predict genotypic value of each inbred line using model 21 of SELEGEN-REML/BLUP software (Resende, 2008). For this analysis, each year was considered one block, and a complete randomized block design was used.

Genomic DNA was extracted from five seeds of each inbred line, using the method described by Schuster et al. (2004). SNP genotyping was made using Axiom Maize Genotyping Array containing 616,201 SNPs, in Affymetrix Lab (Affymetrix Inc., Santa Clara, CA, USA). After excluding the markers with less than $90 \%$ of data and minimum allele frequency lower than 5\%, 418,287 markers were used in association analysis.

Association mapping was performed using the mixed model (MLM) in the statistical software TASSEL version 5.2.12 (Bradbury et al. 2007). The $Q+K$ model was used, where $Q$ is the population structure matrix and $\mathrm{K}$ the Kinship matrix. Kinship matrix was obtained with TASSEL software, and Q matrix was obtained with InStruct software (Gao et al., 2007).

Structure analysis is normally performed before MLM, to use the Q matrix in order to avoid false-positive associations between markers and target characteristic. The structure analysis using InStruct software use the Markov Chain Monte Carlo algorithm (MCMC) with the generalized Bayesian model. The advantage of using the algorithm implemented in the InStruct software is it does not presuppose the HardyWeinberg equilibrium in the population.

In order to obtain a good data convergence, the model estimates the allele frequencies for each simulated subpopulation $(k)$ and then consider the line probability $i$ as belonging to a population $k$. The number of burn-in was 5,000 simulations, with 50,000 replicates (Run Length Periods) and $k$ varying from 2 to 8 . The best $k$ value was the one with the highest value of $\ln$ $\operatorname{Pr}(\mathrm{x} \mid \mathrm{k})$ between all simulated $k$ values.

The associations between the SNP markers and the WLS phenotype in MLM association analysis were significative when $\mathrm{P}<0.01 \%$. The $-\log 10(\mathrm{P})$ was used to obtain the Manhattan Plot graph. Markers identified as significative in MLM were used in multiple regression analysis, to identify non-redundant markers. Multiple regression analysis was made using JMP software (SAS Institute, 1990), using Stepwise model with $5 \%$ probability to enter and remove markers in the model. 


\section{Results and discussion}

\section{Genetic inheritance to white leaf spot resistance}

The field assays for the genetic study were conducted under favorable environmental conditions in order to promote natural infestation of leaf diseases in corn. The incidence and severity of WLS were high throughout the experimental area, with leaf lesions in the upper third of the plants ranging from 0 to $100 \%$ (grades ranged from 1 to 6 - Table 2), allowing a reliable discrimination of resistance levels.
The average scores of the parents were highly contrasting (Table 2). As the score of the susceptible parent (P1) was close to 6 and the score of the resistant parent (P2) was close to 1 , the population in this study must be segregating for all genes related to resistance to WLS. The $F_{1}$ and $F_{2}$ generations had intermediate means between the genitors. The means of backcrossing generations was skewed to the recurrent parent, i.e, the average of $\mathrm{BC}_{1.1}$ was skewed to $\mathrm{P} 1$ average, a $\mathrm{BC}_{1.2}$ average was skewed to $\mathrm{P} 2$ average (Table 2). The average results of the generations evaluated allow considering additive effects acting in the genetic control to WLS resistance.

Table 2. Number of plants evaluated phenotypically, means of severity (sev), variances, and mean variances of severity $\mathrm{V}(\mathrm{sev})$ for resistance to white leaf spot.

\begin{tabular}{ccccc}
\hline GENERATION & NUMBER OF PLANTS & MEAN $(\mathbf{s e v})$ & VARIANCES & $\mathbf{V}(\mathbf{s e v})$ \\
\hline $\mathbf{P}_{\mathbf{1}}$ & 12 & 5.4166 & 0.2651 & 0.0220 \\
$\mathbf{P}_{\mathbf{2}}$ & 12 & 1.4166 & 0.2651 & 0.0220 \\
$\mathbf{F}_{\mathbf{1}}$ & 12 & 4.0833 & 0.0833 & 0.0069 \\
\hline $\mathbf{F}_{\mathbf{2}}$ & 150 & 3.3888 & 0.8407 & 0.0058 \\
$\mathbf{R C}_{\mathbf{1}}$ & 48 & 4.3750 & 0.4521 & 0.0094 \\
$\mathbf{R C}_{\mathbf{1}}$ & 48 & 2.6875 & 0.6023 & 0.0125 \\
\hline
\end{tabular}

The lowest variance was on generations $\mathrm{P} 1$, P2, and F1, i.e., in the generations with no expected genetic variance (Table 2). The variance observed in these generations is expected to be caused by the environment. The other segregating generations $\left(\mathrm{BC}_{1.1}, \mathrm{BC}_{1.2}\right.$, and $\mathrm{F}_{2}$ ) showed the highest variance values. In this case, besides the environmental variance influencing the respective generations, the genetic variance is also present (Kearsey and Pooni, 1996; Cruz et al., 2012).

The heritability in the broad and narrow sense to WLS resistance was $90.08 \%$ and $74.56 \%$ (Table 3), respectively. High heritability for the resistance of the same disease was also reported previously, ranging from $61 \%$ to $88 \%$ (Lopes et al., 2007; Moreira et al. 2009; Juliatti et al., 2013). The high heritability estimated is typical for traits controlled with a small number of genes. In addition, according to Cruz (2005), if the heritability is high, there will be a high correlation between the phenotypic and the genotypic value, so that the differences detected between individuals will translate the true genetic differences and will therefore guarantee the success of the selection strategy.

The genetic component provided the greatest contribution to the expression of WLS resistance $(0.7573)$, and the environment had a low influence (0.0833) (Table 3). The additive genetic component was responsible for the greater contribution of genotypic variance (0.6269), whereas dominance variance was lower (0.1308). Additive and dominance component represents $82.8 \%$ and $17.2 \%$ of the genotypic variance. The estimated average degree of dominance for WLS was 0.2 , also revealing the small effect of dominance and the predominance of additive effect on the resistance to WLS in corn. Several studies have already found the additive gene action to be predominant for WLS resistance in corn (Guimarães et al., 2009; Vivek et al., 2010; Nihei and Ferreira, 2012). Lopes et al. (2007) estimated additive variance corresponding to 74.99 and $84.74 \%$ of the genetic variance, in two populations, and Schuelter et al. (2003) found genetic variance as $92 \%$ of genetic variance when studying resistance to WLS in corn. 
Table 3. Estimate of the phenotypic, genotypic, additive variances, originated from dominance and environmental, heritability in the broad and restricted sense, mean degree of dominance, and estimated number of genes for resistance to white leaf spot (WLS).

\begin{tabular}{lc}
\hline PARAMETER & WLS \\
\hline Phenotypic variance & 0.8407 \\
\hline Genotypic variance & 0.7573 \\
\hline Additive variance & 0.6269 \\
\hline Dominance variance & 0.1304 \\
\hline Environmental variance & 0.0833 \\
\hline Heritability in the broad sense & 0.9008 \\
\hline Heritability in the restricted sense & 0.7456 \\
\hline Mean degree of dominance (based on variances) & 0.2080 \\
\hline Number of genes & 3.19 \\
\hline
\end{tabular}

The estimate of genetic parameters can provide essential information for both the selection and definition of the breeding method and for the nature and magnitude of gene action in the inheritance of the trait. Additive genetic effects allow obtaining more durable and stable resistance, through simple breeding strategies (Cruz et al., 2012), like recurrent selection for quantitative traits with the objective of concentrate favorable alleles over the generations. For traits controlled by a small number of genes, the use of backcross can also be recommended.

Based on the generation study, the estimated number of genes for WLS resistance in the parents used in this study is approximately 3 (Table 3). Lopes et al. (2007) also reported two and three genes conferring WLS resistance, in two sources of resistance. Carson (2001) and Schuelter et al (2003) also estimated the number of genes for WLS control varying from one to four. The results obtained in this work, and the data already reported in diverse independent studies reinforce that the genetic control of WLS resistance in corn is oligogenic, being controlled by a small number of genes.

The additive effects of genetic resistance to WLS also can allow higher selection gains (Cruz et al., 2012). Considering that the selection was performed in $F_{2}$ generation with a selection intensity of $20 \%(\mathrm{i}=1.39)$, there was an estimated gain of 4.34 percentage points for the first cycle after selection, corresponding to approximately $28 \%$ gain per cycle for WLS. This gain would be around ten times higher than values obtained in study of the Arnhold (2008).
Considering the above, in plant breeding programs, the characterization of their resistance sources must first be performed in order to make the selection process efficient, since the character genetic control can vary between different resistance sources (Lopes et al. 2007; Kaefer et al., 2019).

\section{Association mapping for white leaf spot resistance}

The genotypic value of the scores of WLS in the 71 inbred lines, predicted by the REML/BLUP model, varied from 1.4 to 5.4 , with the more frequent scores in the range of 2 to 4 (Figure 1). Based on the assumption used by breeders and pathologist, plants with scores equal or lower than 3 are considered resistant, and plants with scores higher than 3 is considered susceptible. Considering this classification, $55 \%$ of the inbred lines were resistant and $45 \%$ were susceptible.

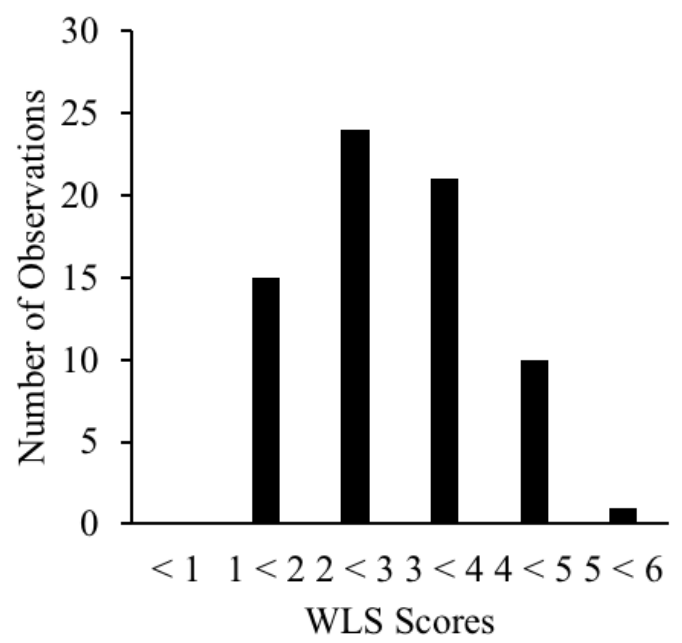

Figure 1. Frequency of the scores for WLS in 71 corn inbred lines used for association analysis. 
Three SNP markers were associated with WLS resistance in this study $(\mathrm{p} \leq 0.001)$, one on each of the chromosomes 2,3 , and 8 , with $\mathrm{R}^{2}$ varying from 0.27 to 0.34 (Figure 2 and Table 4). It can be understood as three genes conferring resistance to WLS in the studied germplasm. In studies carried out with tropical germplasm for resistance to white spot, Lana et al. (2017) mapped QTLs for resistance to WLS on chromosomes 4 and 8 by means of two-parent crossing and evaluation in the F2: 3 generations under different environmental conditions. As for the association mapping carried out by Rossi et al. (2020), identified SNPs on chromosomes 1, 3, $4,5,6,7$, and 8 associated with white spot resistance, some of which co-located with previously mapped QTLs. Despite the partial agreement of the results and the analysis strategies, the importance of chromosome 8 for resistance to WLS is evident.

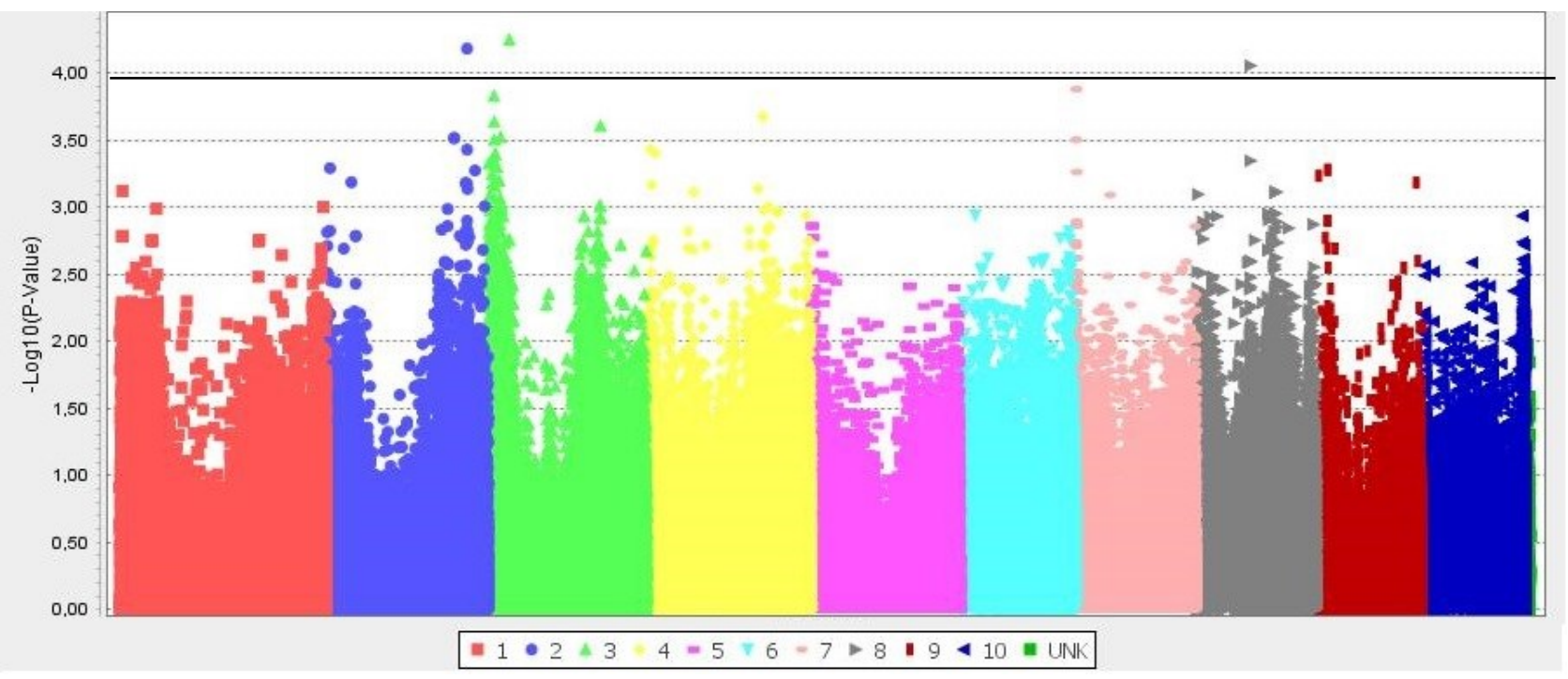

Figure 2. Genome-wide association scan for WLS resistance in corn. The Manhattan Plot $-\log _{10}(p)$ values from the genome-wide scan are plotted against the single nucleotide polymorphism (SNP) positions on the physical map of each chromosome. Each color represents one chromosome of corn. The significance threshold $(p=0.0001)$ is indicated by the horizontal black line.

Table 4. SNP markers associated with white leaf spot resistance in corn identified by Mixed Linear Model (MLM) and $\mathrm{P}<0.01 \%$.

\begin{tabular}{cccccc}
\hline Analysis & SNP Affmetrix ID & chromosome & position & $\mathbf{P}$ & $\mathbf{R}^{\mathbf{2}}$ \\
\hline & Affx-90713222 & 3 & $31,104,219$ & 0.000056 & 0.34 \\
\hline MLM & Affx-91345484 & 2 & $206,217,496$ & 0.000066 & 0.27 \\
\hline & Affx-913781309 & 8 & $79,431,525$ & 0.000088 & 0.33 \\
\hline Multiple & Affx-90713222 & 3 & $31,104,219$ & $<0.0001$ & 0.30 \\
\hline Regression & Affx-91345484 & 2 & $206,217,496$ & $<0.0001$ & $0.50^{*}$ \\
\hline
\end{tabular}

${ }^{*}$ Complete mode $\mathrm{R}^{2}$, when two markers were included in the model.

To evaluate the combined effect of these three markers, it was used in a multiple regression analysis. And to evaluate if there are some redundant effects of the markers, the Stepwise approach was used to select the best regression model. In the multiple regression analysis, two markers were included in the model, Affx-90713222 on chromosome 3 and Affx-91345484 on chromosome 2. The marker AX-91088684 on chromosome 8 was associated with WLS resistance in corn by MLM analysis with $\mathrm{R}^{2}$ of 0.33 and was not included in the multiple regression model. In fact, the inclusion of this marker in the multiple regression model, besides being not significative at $5 \%$ probability, just increased the $\mathrm{R}^{2}$ from 0.50 to 0.52 . It means the gene in chromosome 8 can have a duplicated effect or can be a duplicated gene from one of the other two genes on chromosomes 2 and 3 . Duplicated genes are expected on the corn 
genome, as corn is a diploidized polyploid (Messing, 2009).

The SNP Affx-90713222 is characterized by a change of an Adenine by a Guanine (G/A) in position 31,104,219 bp on chromosome 3, being the allele with A nucleotide associated with the resistance and the alleles with $G$ nucleotide associated with WLS susceptibility. The SNP Affx-91345484 is also characterized by a change of an Adenine by a Guanine (G/A) in position $206,217,496$ bp on chromosome 2, and in this SNP the allele with $G$ nucleotide is associated with the resistance, and the alleles with A nucleotide is associated with WLS susceptibility.

The average score of WLS of the inbred lines with haplotype containing the allele A on SNP Affx-90713222 and allele G on SNP Affx91345484 (haplotype AG) was 2.9, and the average score of WLS of the inbred lines with haplotype containing the allele G on SNP Affx90713222 and allele A on SNP Affx-91345484 (haplotype GA) was 4.23 (Figure 3). This difference in WLS average scores illustrates the effect of these two loci on WLS resistance.

$\mathrm{R}($ Score $\leq 3) \quad \square \mathrm{S}($ Score $>3)$

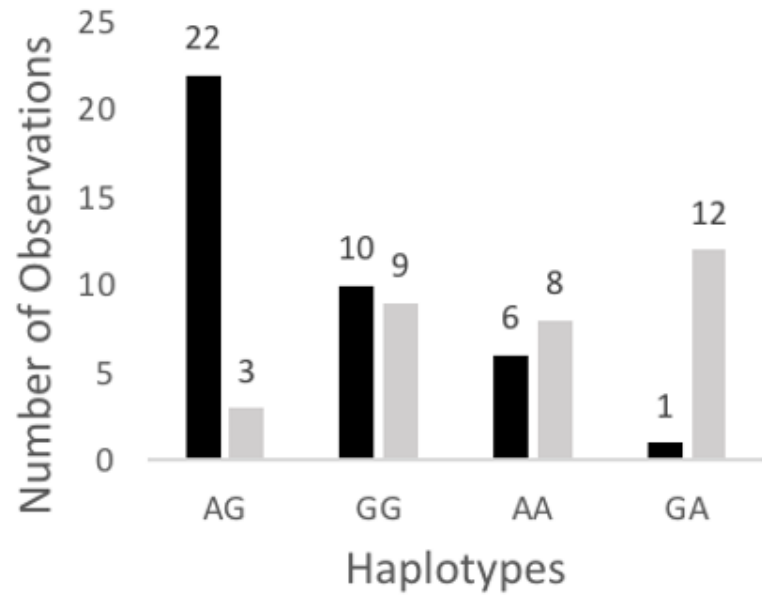

Figure 3. A) Average of WLS scores in the inbred lines with different haplotypes on SNPs Affx-90713222 and Affx-91345484. B) Number of resistant (score $\leq 3$ ) and susceptible (score $>3$ ) inbred lines with each genotype on SNPs Affx-90713222 and Affx-91345484.

Average WLS score of inbred lines with haplotypes AA or GG (containing A nucleotide in both SNPs, or G nucleotide in both SNPs) was intermediate from the resistance and susceptible haplotypes (Figure 3). It means the genes on chromosomes 2 and 3 have an additive effect. It was also illustrated by multiple regression analysis, where the $\mathrm{R}^{2}$ increased by the addition of the SNP on chromosome 2 after the SNP on chromosome 3 (Table 4).

Considering the qualitative classification for WLS, when scores lower or equal to 3 is classified as resistant $(\mathrm{R})$ and scores higher than 3 is classified as susceptible (S), 22 out of 25 inbred lines with $A G$ haplotype have scored lower than 3 , and 12 out of 13 inbred lines with haplotype GA have scored higher than 3. Inbred lines with haplotypes AA or GG can be resistant or susceptible (Figure 3). The haplotype AG (R) or GA (S) identified correctly $89.5 \% \mathrm{R}$ or $\mathrm{S}$ phenotype by the genotype. Just three out of 38 inbred lines with the R or S haplotype don't have the phenotype identified by the genotype.

WLS resistance in corn is sometimes considered a quantitative trait. In the genetic study, we observed high heritability and estimated 3 genes for resistance to WLS in the parents evaluated. Other related studies (Carson, 2001; Schuelter et al 2003) also reported high heritability and a small number of genes controlling WLS resistance. With the consistency high heritability, this trait cannot be considered a quantitative trait. In the Association analysis, we identified three regions associated 
with WLS resistance, each one with $\mathrm{R}^{2}$ around 0.3 . And in multiple regression analysis, we observed that just two of these regions were enough for resistance to WLS in corn. Based on these results, we can consider the resistance to WLS as oligogenic, and call the resistance loci as genes and not QTL.

\section{Conclusion}

The SNP markers identified in the association analysis can be used in marker assisted selection for resistance to WLS in corn breeding programs after validated in the specific germplasm of each breeding program.
The additive nature of the resistance genes allows breeding for resistance more easily, but also requires the resistance genes in both parents of the hybrids, as the heterozygous genotype is just partially resistant, and for complete resistance, the hybrid genotype in the resistant genes need to be homozygous.

\section{Acknowledgements}

The authors thank COODETEC, for the availability of the structure and execution of the experiment, and also UNIOESTE and CAPES, for the granting of a master's degree scholarship to the first author.

\section{References}

ARNHOLD, E. 2008. Seleção para resistência a doenças foliares em famílias S1 de milho pipoca. Revista Ceres, 55(2):89-93.

BORSOI, F.T.; SCHMITZ, L.; WORDELL FILHO, J.A.; NESI, C.N. (2018). Mancha branca no milho: etiologia e controle. Agropecuária Catarinense, 31(3):31-34.

BRADBURY, P.J.; ZHANG, Z.; KROON, D.E.; CASSTEVENS, T.M.; RAMDOSS, Y.; BUCKLER, E.S. 2007. TASSEL: software for association mapping of complex traits in diverse samples. Bioinformatics, 23(19):2633-2635.

CARSON, M.L. (2001). Inheritance of resistance to Phaeosphaeria leaf spot of maize. Plant disease, 85(7), 798-800.

CASTRO, C.M.; PEREIRA, A.S. 2008. Mapeamento por associação em plantas: conceitos básicos e perspectivas de uso no melhoramento de batata. Pelotas: Embrapa Clima Temperado, 30p. (Documentos, 248).

CHAVES NETO, J.R.; TRAVESSINI, M.; BOSCAINI, R.; LEDUR, N.; COSTA, I. (2017). Eficácia da aplicação foliar de fungicidas no controle de mancha-branca do milho. Revista Tecnologia \& Ciência Agropecuária, 11(1): 31-36.

COSTA R.V.; COTA L.V.; SILVA, D.D.; MEIRELLES, W.S.; LANZA, F.E. 2012. Viabilidade técnica e econômica da aplicação de estrobilurinas em milho. Tropical Plant Pathology, 37(4):246-254.

CRUZ, C.D. 2013. Genes: um pacote de software para análise em estatística experimental e genética quantitativa. Acta Scientiarum. Agronomy, 35(3): 271-276.

CRUZ, C.D. 2005. Princípios de genética quantitativa. Editora UFV, Viçosa, MG.

CRUZ, C.D.; REGAZZI, A.J.; CARNEIRO, P.C.S. 2012. Modelos Biométricos Aplicados ao Melhoramento Genético. Editora UFV, 4. ed. v.2 Viçosa, MG. 
GAO, H.; MCDONNELL, A.; HARRISON, D.A.; MOORE T.; ADAM, S.; DALY, K.; ESMONDE, L.; GOLDHILL D.R., PARRY, G.J.; RASHIDIAN, A.; SUBBE, C.P.; HARVEY, S. 2007. Systematic review and evaluation of physiological track and trigger warning systems for identifying at-risk patients on the ward. Intensive Care Medicine, 33(4): 667-6679.

GARRETT, K. A.; ANDERSEN, K. F.; ASCHE, F.; BOWDEN, R. L.; FORBES, G.A.; KULAKOW, P. A.; ZHOU, B. 2017. Resistance genes in global crop breeding networks. Phytopathology, 107(10), 1268-1278.

GUIMARÃES, P.S.; PATERNIANI, M.E.A.G.Z.; DUDIENAS, C.; LÜDERS, R.R.; GALLO, P.B. 2009. Capacidade combinatória para resistência à mancha branca em linhagens endogâmicas de milho. Summa Phytopathologica, 35(4):282-287.

JULIATTI, F.C.; PEDROSA, M.G.; JULIATTI, B.C.M.; BELOTI, I.F.; FIGUEIRÓ, A.A. 2013. Identificação de QTLs associados à resistência parcial à mancha branca do milho. Bioscience Journal, 29(5):1163 -1178.

KEARSEY, M. J.; POONI, H.S.C.N. 1996. Genetical analysis of quantitative traits. Chapman and Hall Publishers, New York.

KRAWCZYK, K.; KAMASA J.; ZWOLINSKA A.; POSPIESZNY, H. 2010. First report of Pantoea ananatis associated with leaf spot disease of maize in Poland. Journal of Plant Pathology, 92(3): 807-811.

LANA, U.G.D.P.; SOUZA, I.R.P.; NODA, R.W.; PASTINA, M.M.; MAGALHAES, J.V.; GUIMARAES, C.T. 2017. Quantitative trait loci and resistance gene analogs associated with maize white spot resistance. Plant Disease, 101(1): 200-208.

LOPES, M.T.G.; LOPES R.; BRUNELLI, K.R.; SILVA, H.P. DA; MATIELLO, R.R.; CAMARGO, L.E.A. 2007 Controle genético da resistência à mancha-de-Phaeosphaeria em milho. Ciência Rural, 37(3):605-611.

KAEFER, K.A.C.; SCHUELTER, A.R.; SCHUSTER, I., MARCOLIN, J.; VENDRUSCOLO, E.C.G. 2019. Identification and characterization of maize lines resistant to leaf diseases. Semina: Ciências Agrárias, 40(2):517-526.

MACKAY, I.; POWEL, W. 2007. Methods for linkage disequilibrium mapping in crops. Trends in Plant Science, 12(2): 57-63.

MATHER, S.K.; JINKS, J.L. 1982. Biometrical genetics. Cambridge University Press, Cambridge.

MESSING J. 2009. The Polyploid Origin of Maize. In: Bennetzen J.L., Hake S. (eds) Handbook of Maize. Springer, New York, NY.

MOREIRA, J.U.V.; VIEIRA, D.A.; SOUZA, B.A.P.; SOUZA JÚNIOR, C.L. 2009. QTL mapping for reaction to Phaeosphaeria leaf spot in a tropical maize population. Theoretical and Applied Genetics, 119(8): 1361-1369.

PINK, D.A.C.; HAND, P. 2003. Plant resistance and strategies for breeding resistant varieties. Plant Protection Science-Prague, 38, 9-14.

MUNDT, C.C. 2014. Durable resistance: a key to sustainable management of pathogens and pests. Infection, Genetics and Evolution, 27: 446-455. 
NIHEI, T.H.; FERREIRA, J.M. 2012. Análise dialélica de linhagens de milho com ênfase na resistência a doenças foliares. Pesquisa Agropecuária Brasileira, 47(3): 369-377.

RESENDE, M.D.V. 2008. Genômica quantitativa e seleção no melhoramento de plantas perenes e animais. Embrapa Florestas, Colombo, PR.

ROSSI, E.S.; KUKI M.C.; PINTO R.J.; SCAPIM C.A.; FARIA M.V.; DE LEON N. 2020. Genomicwide association study for white spot resistance in a tropical maize germplasm. Euphytica, 216(1): 1-15.

SAS. INSTITUTE INC.1990. SAS/STAT user's guide, version 6.0. 3.ed. Cary, NC.

SCHIPANSKI, C.A. 2011. Manual de identificação e manejo das doenças do milho. Fundação $\mathrm{ABC}$, 3. ed. Castro, PR.

SCHUELTER, A.R.; SOUZA, I.R.P.; TAVARES, F.F.; SANTOS, M.X.; OLIVEIRA, E.; GUIMARÃES, C.T. 2003. Controle genético da resistência do milho à mancha por Phaeosphaeria. Revista Brasileira de Milho e Sorgo 2(1): 80-86.

SCHUSTER, I.; QUEIROZ, V.T.; TEIXEIRA, A.I.; BARROS, E.G.; MOREIRA, M.A. 2004. Determinação da pureza varietal de sementes de soja com o auxílio de marcadores moleculares microssatélites. Pesquisa Agropecuária Brasileira, 39(3): 247-253.

SIBIYA, J.; TONGOONA, P.; DERERA, J.; VAN RIJ N.; MAKANDA, I. 2011. Combining ability analysis for Phaeosphaeria leaf spot resistance and grain yield in tropical advanced maize inbred lines. Field Crops Research, 120(1): 86-93.

SILVA, D.D.; COTA L.V.; COSTA, R.V. 2015. Doenças. In: Silva DD, Cota LV, Costa RV Cultivo de milho. 9. Ed. Sete Lagoas: Embrapa Milho e Sorgo. (Sistemas de produção, 1).

SOTO-CERDA, B.J.; CLOUTIER, S. 2012. Association mapping in plant genomes. In: Caliskan M. (ed) Genetic diversity in plants. InTech, Rijeka, pp. 29-54.

VAN ESSE, H.P.; REUBER, T.L.; VAN DER DOES, D. (2020). Genetic modification to improve disease resistance in crops. New Phytologist, 225(1), 70-86.

VIVEK, B.; ODONGO O.; NJUGUNA J.; IMANYWOHA, J.; BIGIRWA, G.; DIALLO, A.; PIXLEY, K. 2010. Diallel analysis of grain yield and resistance to seven diseases of African maize (Zea mays L.) inbred lines. Euphytica, 172(3): 329-340. 